\title{
Evaluation of Three External Marking Methods of Farmed Atlantic Salmon for the Future Use of Differentiating it From Wild Atlantic Salmon
}

\author{
Atle Mortensen, Oyvind J Hansen and Velmurugu Puvanendran*
}

Nofima AS, Muninbakken 9-13, 9291 Tromsø, Norway

\begin{abstract}
We evaluated different external marking methods for farmed salmon to differentiate it from wild salmon without any special tools. Three marking methods were tested: 1) Adipose fin (AF) removal, 2) Freeze branding (FB) and 3) Visible Implant Elastomer (VIE). Location of the marking method on the fish, combination of marking methods and degree of AF removal were tested in three experiments. Atlantic salmon parr weighing $20 \mathrm{~g}$ were marked either with individual marks or in combination of two. Further all the fish were also PIT tagged. They were kept in freshwater tanks for 4 months and later after smoltification, smolts were transferred to sea cages and kept for another 4 months. At the end of four (freshwater phase) and ten (sea cages) months, growth, survival and mark retention were recorded. All these methods had no significant effects on growth and survival compared to the control (no mark but only PIT tagged). Our results showed that of these methods, only complete removal of the adipose fin met the requirements for mark retention and was the cheapest and easiest method to automate. However, a larger commercial scale long-term testing of the AF clipping is required prior to implementing it. Further development of an automated fin clipping in combination with vaccination and an open discussion with consumers, buyers, and environmental groups are also warranted.
\end{abstract}

Keywords: Farmed Atlantic salmon; Escape; Marking; Adipose fin clip; Freeze brand; VIE

\section{Introduction}

Atlantic salmon escaping from sea cages in Norway has been increasing until 2006 and since then due to the strict implementation of certification rules by the Norwegian Government; salmon escaping from sea cages has been reduced [1]. However still fish escape is a major challenge for the salmon farming industry. It is suggested that farmed fish selected for trait may outcompete for resources (food, territory etc.) with wild fish [2] and genetic pollution can occur through interbreeding with wild fish [3]. However, the actual impact of the escapees on wild fishes has not been well understood because the risk posed by the escapees depends on the magnitude and the frequency of the escape events. It is suggested that salmonid fish escapes could be as high as one to two million worldwide [4]. Fish escapes can occur due to several reasons, including harsh weather conditions, human error, poor cage technology, poor cage maintenance, and poor decision-making [3]. To cope with the potential problems caused by escaped salmon suggestions are emerging to mark all the farmed fish using externally visible tags/ marking so that any escaped salmon can be easily distinguished from wild salmon, and eventually traced back to the farm it has escaped from using genetic markers [5]. Selection of an appropriate external marking method is largely depending on the purpose of the marking, cost effectiveness, retainability of the mark, effects on fish growth, survival and welfare and logistics such as detectability of the mark and legality of the method.

There are many different methods used for marking and tagging fish, each with their own advantages and disadvantages [6]. For any of the available techniques to be valid, marks must be permanent or at least last long without any detrimental effects on the target fish species growth, reproduction or survival and health and welfare. Various marking methods, such as fin clipping, genetic marking, and external and internal tags have been used to identify individual fish over the decades in fisheries related studies [7-12]. In North America, annually various salmon species in several millions are externally marked for stock enhancement purposes [13]. However, very few studies have attempted using marking methods to identify the escaped farmed fishes [5,14-17]. In the recent past, suggestions are emerging to mark all farmed fish with externally visible tags/marking so that any escaped fish can be identified easily $[18,19]$. However, tracing of escaped fishes of farmed origin to the initial sea cage/farm source is much more difficult than for terrestrial animals because of difficulties in catching and identifying them among vast number of fish species and individuals. To monitor and identify farmed fish escapees an identification system that distinguishes between farmed and wild fish is necessary. Precise genetic markers to differentiate farmed and wild fish are available but these methods are expensive [17,20,21]. However, if the fish can initially be identified as escaped fish with common external marks for all farms, then using the genetic markers the escaped fish can be traced back to the origin of the farm $[15,22]$. This approach will reduce the cost of identifying the escaped fish to the origin of the farm using genetic markers.

Tags or marks used in fish studies fall into two categories, external and internal tags. External marks include fin clipping, cold branding, carlin tagging, coded wire tagging and visible implant marks (such as visible implant elastomer/VIE) which are easily detectable and no special equipment is required for detection [6,23-25]. Most of the external marks/tags used currently are inexpensive, or simple to produce, which may make their use effective. The major disadvantages of external marker/tags are that they may affect growth, survival, and

*Corresponding author: Velmurugu Puvanendran, Nofima AS, Muninbakken 9-13, 9291 Tromsø, Norway, Tel: +47 77629216; E-mail: velmurugu.puvanendran@nofima.no

Received June 03, 2016; Accepted October 24, 2016; Published October 26 , 2016

Citation: Mortensen A, Hansen OJ, Puvanendran V (2016) Evaluation of Three External Marking Methods of Farmed Atlantic Salmon for the Future Use of Differentiating it From Wild Atlantic Salmon. J Aquac Res Development 7: 451. doi: 10.4172/2155-9546.1000451

Copyright: (c) 2016 Mortensen A, et al. This is an open-access article distributed under the terms of the Creative Commons Attribution License, which permits unrestricted use, distribution, and reproduction in any medium, provided the original author and source are credited. 
welfare due to penetration of the skin, providing an access route for infections as well as negative market and customer responses [26,27]. Major differences between the external marks and tags are that the tags may affect behaviour and swimming/hiding performance of the fish or may get algal growth which may make the identification difficult or may become entangled in aquatic vegetation and tag losses may be high $[6,25,28,29]$. In contrary, external marks do not pose any of these problems; however, external marks such as freeze branding and visible implant marks may deteriorate with time $[6,8,30]$. Studies have shown that success of any external marking/tagging methods may be species dependent [31], thus a careful laboratory studies should be carried out before implementing any marking/tagging project.

Internal tags such as pit tags and acoustic tags are also used in several studies [27,32]. Internal tags are inserted or injected into the fish (body cavity, muscle), thus may require surgery and special equipments. The main advantage of internal tags is that they can be used in individual fish and tag losses are minimal [27]. Passive Integrated Transponder Tags (PIT tags), internal coded wire tags, and acoustic tags are some examples of internal tags. While these tags, except acoustic tags, may have minimal influence of the behaviour, growth, and survival of the fish, the tags and the equipments may be expensive and tagging procedure may be costly and time consuming.

Approximately, annually 300 million salmon smolts are produced in Norway and marking all these fish will be a challenging task. Marking must be efficient, economical, and in accordance with applicable fish handling regulations. The marking of salmon can take place either manually or automatically. In a commercial operation, all Atlantic salmon smolts are vaccinated before sea cage transfer. It is recommended that any marking should occur in conjunction with vaccination to avoid causing fish to extra anaesthesia and handling which would also be far more cost effective than performing two separate operations [33].

For the reasons described above, in the current study we have selected the external marks over external and internal tags. Among the available external marks, we have selected Visible Implant Elastomer (VIE), Adipose fin clipping (AF clipping) and freeze branding (FB) mainly because all these three methods can be used for all sizes of the fish [10,34]. To our knowledge, no studies have examined the effects of external marks on growth and survival of the fish and the retention of the marks in both freshwater and sea cages covering parr and smolt stages. The major objectives of this study were to evaluate 1 ). The effects of individual and combined [35] marking methods on growth and survival of the fish at freshwater and sea cages, and retention of the mark (Experiments 1-3; Tables 1 and 2). Assessment of the different marking methods regarding suitability for manual and automatic marking in a large-scale operation, and costs associated with the various brand methods.

\section{Materials and Methods}

Atlantic salmon parr were produced at the Aquaculture Research Station in Tromsø and in total 1000 fish weighing approximately 20 $\mathrm{g}$ were used. Of these, 800 salmon parr were externally marked with either FB, VIE or AF clipping and with different combinations to conduct three different comparative studies (Table 1). In addition, 100 fish with PIT tags (Sokymat, Switzerland) and 100 fish without PIT tag (PT and NPT, respectively) were used as controls to evaluate the effect of external marking and PIT-tag marking, respectively on growth and survival. Both PT and NPT did not receive any external markings. All externally marked fish were also tagged with PIT tags inserted in the abdominal cavity to identify the fish if any of the marks become illegible during the experiment. All the fish were anesthetized using metacaine (MS-222) prior to marking. VIE was prepared per the instructions provided by the manufacturers [36] and a yellow VIE was used. VIE tags were injected in two different positions on the fish (Table 1) as a liquid that soon cured into a pliable, biocompatible solid. Adipose fin was removed using a sharp surgical scissor. The fin was removed either completely or $75 \%$ of the top adipose fin to see if an incomplete removal of the fin (by error) would results in more regeneration of the fin. Freeze branding was done using liquid nitrogen in a container and equal sign (=) shaped a copper metallic rod. The other end of the equal sign was in direct contact with the liquid nitrogen, which made the equal sign shape to become very cold $\left(\mathrm{ca} .-80^{\circ} \mathrm{C}\right)$. The fish were slightly pressed against the cold metallic rod for 3 seconds to make a cold burn mark on the fish and FB marks were made in two positions (Table 1).

To avoid tank effect, all fish were placed in the same tank after marking. The fish were fed and cared for per standard procedure. Any dead fish were removed and recorded daily. Water parameters (daily oxygen and temperature and weekly ammonia) were also monitored. After marking, fish were kept in tanks with fresh water at ambient fluctuating temperature $\left(3.0^{\circ} \mathrm{C}\right.$ to $\left.10.6^{\circ} \mathrm{C}\right)$ for 4 months. At the end of 4 months, the fish were smoltified using standard smoltification procedures, which lasted for about 4 weeks. Four weeks after smoltification, salmon smolts were transferred to sea cage and were kept for 4 months.

At the end of freshwater phase (4 months after start of the experiment) and sea water phase (10 months after start of the experiment), all fish were examined and length, weight, retention of the marks, deformities and mortality were recorded. During recording,

\begin{tabular}{|c|c|c|}
\hline Experiment & Mark/Tag & Detail \\
\hline \multirow{7}{*}{ Experiment I } & AF-C (Adipose Fin - Complete) & \multirow{7}{*}{$\begin{array}{c}\text { Examine the effects of individual and combined marking methods on growth, } \\
\text { survival, and mark retention. }\end{array}$} \\
\hline & VIE-BEL (VIE - Below Eye Lid) & \\
\hline & FB-DoT (Freeze Brand - Dorsally on Top) & \\
\hline & $A F-C+V I E-B E L$ (combination of AF and VIE) & \\
\hline & AF-C + FB-DoT (combination of AF and FB) & \\
\hline & PT (Pit Tag) & \\
\hline & NPT (No Pit Tag) & \\
\hline \multirow{3}{*}{ Experiment II } & VIE-BEL, VIE-BD (VIE - Below Dorsal fin) & \multirow{3}{*}{$\begin{array}{l}\text { Examine the effects of location of marking (FB and VIE marking) on mark } \\
\text { retention. }\end{array}$} \\
\hline & FB-DoT, FB-BDF (FB-Below Dorsal Fin) & \\
\hline & PT, NPT & \\
\hline Experiment III & AF-C, AF-IC (AF-InComplete), PT, NPT & Examine the effects of $\mathrm{AF}-\mathrm{IC}$ and $\mathrm{AF}-\mathrm{C}$ on mark retention. \\
\hline
\end{tabular}

Table 1: Details of the marking methods used to mark the fish and the experiments that they were used. Number of fish used for each marking method was 100 . Fish/ data from VIE-BEL, FB-DoT, PT and NPT were used for interchangeably in Experiment I and II while AF-C, PT and NPT were used interchangeably in Experiment I and II. 


\begin{tabular}{|c|c|c|c|c|c|c|}
\hline & \multicolumn{2}{|c|}{ Weight (g) } & \multicolumn{2}{|c|}{ Length $(\mathrm{cm})$} & \multicolumn{2}{|c|}{ Survival (\%) } \\
\hline & $4 \mathrm{~m}$ & $10 \mathrm{~m}$ & $4 m$ & $10 \mathrm{~m}$ & $4 \mathrm{~m}$ & $10 \mathrm{~m}$ \\
\hline \multicolumn{7}{|c|}{ Experiment I } \\
\hline AF-C & $31.5(5.9)$ & $378(78)$ & $13.4(0.83)$ & $30.7(2.2)$ & 100 & 91 \\
\hline FB-DoT & $32.3(5.1)$ & $380(68)$ & $13.6(0.66)$ & $30.8(2.0)$ & 98 & 89 \\
\hline VIE-BEL & $32.3(5.3)$ & $376(69)$ & $13.6(0.77)$ & $30.7(2.1)$ & 95 & 91 \\
\hline AF-C + FB-DOT & $31.8(6.0)$ & $359(85)$ & $13.4(0.87)$ & $30.0(3.2)$ & 98 & 89 \\
\hline AF-C + VIE-BEL & $31.7(5.1)$ & $379(73)$ & $13.5(69)$ & $30.7(2.2)$ & 96 & 93 \\
\hline PT & $32.2(6.5)$ & $367(97)$ & $13.5(0.83)$ & $30.4(3.0)$ & 99 & 86 \\
\hline NPT & $31.8(6.5)$ & 369 (95) & $13.5(0.95)$ & $30.3(3.1)$ & 100 & 84 \\
\hline \multicolumn{7}{|c|}{ Experiment II } \\
\hline FB-DoT & $32.3(5.1)$ & $380(68)$ & $13.6(0.66)$ & $30.8(2.0)$ & 98 & 89 \\
\hline FB-BDF & $31.9(6.3)$ & $370(81)$ & $13.4(0.93)$ & $30.4(2.3)$ & 99 & 88 \\
\hline VIE-BEL & $32.3(5.3)$ & $376(69)$ & $13.6(0.77)$ & $30.7(2.1)$ & 95 & 91 \\
\hline VIE-BD & $29.9(6.0)$ & $338(85)$ & $13.2(0.96)$ & $29.6(2.9)$ & 99 & 88 \\
\hline PT & $32.2(6.5)$ & $367(97)$ & $13.5(0.83)$ & $30.4(3.0)$ & 99 & 86 \\
\hline NPT & $31.8(6.5)$ & 369 (95) & $13.5(0.95)$ & $30.3(3.1)$ & 100 & 84 \\
\hline \multicolumn{7}{|c|}{ Experiment III } \\
\hline AF-C & $31.5(5.9)$ & $378(78)$ & $13.4(0.83)$ & $30.7(2.2)$ & 100 & 91 \\
\hline AF-IC & $31.9(5.9)$ & $363(71)$ & $13.5(0.77)$ & $30.2(2.0)$ & 97 & 90 \\
\hline PT & $32.2(6.5)$ & $367(97)$ & $13.5(0.83)$ & $30.4(3.0)$ & 99 & 86 \\
\hline NPT & $31.8(6.5)$ & 369 (95) & $13.5(0.95)$ & $30.3(3.1)$ & 100 & 84 \\
\hline
\end{tabular}

Table 2: Weight, total length and survival of Atlantic salmon parr and smolts in freshwater (4 months) and sea cages (10 months), respectively from different experiments.

individual fish were first identified by the pit tag reader connected to a computer that had the original tagging file on an excel spreadsheet. Once identified, marking on the fish was examined. VIE marks are more fluorescent under UV light and for this reason a UV light was used when no VIE marks were visible. When an external mark was detected, it was categorized as follows depending on the marking; $\mathrm{AF}$ $(0,25,50,75$ and 100 regeneration of adipose fin), FB (dark, light, no mark) and VIE (readable without UV light, readable only with UV light, not readable even with UV light).

Growth data from experiment I-III were analysed using one-way ANOVA and the data were test for normality to satisfy the assumptions of ANOVA. When a significant treatment effect was found, multiple comparisons between different treatments were made using Bonferroni correction. Survival data from experiment I-III were analysed using Chi-square test and the significance level was set at 0.05 .

We have also consulted experts in the field of marking and tagging of Atlantic salmon and Pacific salmon regarding suitability, cost, and easiness of implementation. Information was obtained from Department of Fisheries and Oceans, British Columbia, Canada, private tag manufacturers in USA and fish farmers, and vaccination equipment producers in Norway. We included price of marking and tagging equipment and of tags, and salaries in our cost calculations.

The experiment complied with the guidelines of the Norwegian Animal Welfare Act for the use of laboratory animals and all the personnel participated in the experiment have the required training on working and designing experiments with animals.

\section{Results}

Overall, marking methods had no significant effects on the growth of the Atlantic salmon parr in freshwater phase (for weight $\mathrm{p}=0.06$ and for length $\mathrm{p}=0.102$ ). However, marking method had a significant effect on the weight of the Atlantic salmon smolts in saltwater phase but no significant effects were found on length ( $\mathrm{p}=0.025$ and 0.054 , respectively;
Table 2). Multiple comparisons indicated that only smolts with VIEBD had significantly lower weight than smolts with FB-DoT $(p=0.033)$ and AC+VIE-BEL $(\mathrm{p}=0.038)$ in saltwater phase. In Experiment I and III, marking methods had no significant effects on weight $(\mathrm{p}=0.564$ and 0.712 , respectively) and length ( $\mathrm{p}=0.365$ and 0.619 , respectively) of smolts in saltwater phase. However, in Experiment II marking method had significant effects on the weight of the smolts at the saltwater phase $(\mathrm{p}=0.019)$ and only smolts with VIE-BD had significantly lower weight than smolts with FB-DoT $(p=0.016)$ and AC + VIE-BEL $(p=0.049)$. No significant differences in survival of salmon parr ( $p=0.082,0.096$ and 0.109 for Experiments I, II and III, respectively) or smolts ( $\mathrm{p}=0.431$, 0.744 and 0.384 for Experiments I, II and III, respectively) were found among the treatments (Table 2). No fish died within the first 6 weeks after the external marking were performed. PIT tagging had no effect on the growth and survival of salmon parr or smolts (Table 2).

Complete removal of the adipose fin produced better results in terms of mark retention compared to FB and VIE marking (Table 3). Mark retention of AF-C was above $97 \%$ when it was used alone and above $98 \%$ when it was used in combination with freeze brand or VIE marking. Combination of FB or VIE with AF-C did not improve the retention of the marking. Mark retention of $\mathrm{FB}$ was remarkably high when used alone or in combination with $\mathrm{AF}-\mathrm{C}$ at the freshwater phase, however all the FB marks were completely disappeared at 10 months (6 months in saltwater). Retention of VIE tags were relatively poor both at 4 and 10 months of the experiment when UV light was used and without the use of UV light, the mark retention was even poorer. When used in combination with AF-C, the readability did not improve much.

The location of marking of FB and VIE had no significant effect on the growth or survival of the fish (Table 2) at 4 and 10 months. Mark retention of FB-BDF was higher than the FB-DoT at 4 months (Table 4), however, almost all the FB marks disappeared irrespective of the location at 10 months. VIE-BD showed higher mark retention than VIE-BEL (99\% and 74\%, respectively) at 4 months. Similar trend 


\begin{tabular}{|c|c|c|c|c|c|c|c|c|c|c|}
\hline \multirow{2}{*}{ Category } & \multicolumn{2}{|c|}{ AF-C } & \multicolumn{2}{|c|}{ FB-DoT } & \multicolumn{2}{|c|}{ VIE-BEL } & \multicolumn{2}{|c|}{ AF-C + FB-DoT } & \multicolumn{2}{|c|}{ AF-C + VIE-BEL } \\
\hline & $4 \mathrm{~m}$ & $10 \mathrm{~m}$ & $4 \mathrm{~m}$ & $10 \mathrm{~m}$ & $4 \mathrm{~m}$ & $10 \mathrm{~m}$ & $4 \mathrm{~m}$ & $10 \mathrm{~m}$ & $4 \mathrm{~m}$ & $10 \mathrm{~m}$ \\
\hline $0 \%$ regeneration $(\mathrm{AC})$ & 98 & 97 & -- & -- & -- & -- & 100 & 100 & 98 & 98 \\
\hline $25 \%$ regeneration $(A C)$ & 2 & 3 & -- & -- & -- & -- & -- & -- & 2 & 2 \\
\hline Dark Mark (FB) & -- & -- & 91 & -- & -- & -- & 99 & -- & -- & -- \\
\hline Light Mark (FB) & -- & -- & 6 & -- & -- & -- & 1 & -- & -- & -- \\
\hline No Mark (FB) & -- & -- & 3 & 100 & -- & -- & -- & 100 & -- & -- \\
\hline Readable without light (VIE) & -- & -- & -- & -- & 32 & -- & -- & -- & 58 & -- \\
\hline Readable with light (VIE) & -- & -- & -- & -- & 42 & 29 & -- & -- & 29 & 44 \\
\hline Not readable (VIE) & -- & -- & -- & -- & 26 & 71 & -- & -- & 13 & 56 \\
\hline
\end{tabular}

Table 3: Mark retention (\%) of selected marking methods at 4 and 10 months of the experimental period in experiment I.

\begin{tabular}{|c|c|c|c|c|c|c|c|c|}
\hline \multirow{3}{*}{ Category } & \multicolumn{8}{|c|}{ Marking Methods } \\
\hline & \multicolumn{2}{|c|}{ FB-DoT } & \multicolumn{2}{|c|}{ FB-BDF } & \multicolumn{2}{|c|}{ VIE-BEL } & \multicolumn{2}{|c|}{ VIE-BD } \\
\hline & $4 \mathrm{~m}$ & $10 \mathrm{~m}$ & $4 \mathrm{~m}$ & $10 \mathrm{~m}$ & $4 \mathrm{~m}$ & $10 \mathrm{~m}$ & $4 \mathrm{~m}$ & $10 \mathrm{~m}$ \\
\hline Dark Mark (FB) & 92 & -- & 100 & -- & -- & -- & -- & -- \\
\hline Light Mark (FB) & 6 & -- & -- & 4 & -- & -- & -- & -- \\
\hline No Mark (FB) & 2 & 100 & -- & 96 & -- & -- & -- & -- \\
\hline Readable without light (VIE) & -- & -- & -- & -- & 32 & -- & 71 & -- \\
\hline Readable with light (VIE) & -- & -- & -- & -- & 42 & 29 & 28 & 61 \\
\hline Not readable (VIE) & -- & -- & -- & -- & 26 & 71 & 1 & 39 \\
\hline
\end{tabular}

Table 4: Mark retention (\%) of FB and VIE markings at two different body locations at 4 and 10 months of the experimental period in experiment II.

continued at 10 months, however, fewer numbers of fish retained the mark for both VIE-BD and VIE-BEL (Table 4).

The complete or incomplete removal of adipose fin had no significant effect on the growth and survival at 4 and 10 months (Table 2). For AF-C, only a small fraction of fish showed regeneration of adipose fins whereas for AF-IC almost $50 \%$ of the fish showed $25 \%$ more regeneration (i.e., $50 \%$ adipose fin) and some fish from AF-IC showed more than $50 \%$ regeneration (Table 5 ).

Handling time of a fish for manual adipose fin clipping took about 3-4 seconds. For FB, fish were kept in contact with cold metallic rod for 3 seconds and the total time for handling one fish was about 4-5 seconds. We did not systematically measure the time it took for the manual injection of the VIE to the fish but it was considerably longer than in FB and AF clipping methods. Our analysis showed that manual marking was expensive for all the three marking methods selected in this study. The cost would become lower if the marking operation is done using electronic and mechanical equipments, i.e., semi- and fully automated system (Table 6). There is a large uncertainty regarding the costs of the different marking methods, but our analysis indicated that AF clipping would be the least costly marking method whether it is done by manual or automated system, followed by FB and VIE.

\section{Discussion}

In our study, we covered both freshwater and saltwater phase of Atlantic salmon, although fish were in the sea cages only for 6 months. Nevertheless, our study provides insight on the differences retention of external marks on fish both in freshwater and saltwater. Studies covering both freshwater (parr) and saltwater (smolts) phases of salmonids in external mark retention is limited. Salinity (seawater) may not be directly responsible for skin colour changes in salmonid fish but smoltification may be responsible for skin colour changes from silvery shinny skin in parr to darker skin in smolts [37-39]. This change in colour may have some effects on the retention of some external marks as seen in the VIE and FB marked fishes in our study. Studies of mark and recapture of returning salmonid fish have been done but the percentage of returning fish are very low, ranging from $2 \%$ [40] to
$25 \%$ [41] and, the number of retuning fish depends on release site and size at the time of release. However, these survival estimates were based on returning fish with retained marks/tags and did not considered the loss of the marks.

Our results showed that except for VIE-BD none other marking methods that we have used in this study affected the growth of salmon parr or smolts. Further, no mortality for 6 weeks post marking indicates none of these three marking methods may have affected the welfare of the fish. Survival of salmon parr and smolts was also not affected by the marking methods that we have used in this study. Similar results have been shown in other species such as walleye, Sander vitreus using fin clipping and VIE as markers [42], Atlantic salmon using FB [43], rainbow trout, Salmo gairdneri (Oncorhynchus mykiss) using FB and VIE markers [44], Brown trout, Salmo trutta using VIE markers [45] and Coho salmon Oncorhynchus kisutch using complete and incomplete AF clipping [46]. Our results indicated that all of the externally visible markers that we used in this experiment could be used in Atlantic salmon without any major adverse effects on growth and survival.

In our study, the complete AF clipping had a higher retention rates compared to FB-DoT and VIE-BEL at 4 and 10 months post marking, thus double marking did not improve the retention rate. Double marking/tagging is also an important method to estimate tag loss and to increase detection rates in case of loss of one tag. Few studies have examined if double marking methods would give reliable fish recovery data compare to single marking method [35]. Comparing Floy anchor and VIE tags for the tag retention after 6 months and visibility, Walsh and Winkleman [35] reported that both tags had higher retention but VIE tags were more visible. However, double tagging did not improve the detection rate mainly because the retention rates for both tags were higher. McFarlane et al. [47] suggested that double marking is useful when both external marking has higher rate of loss.

Complete disappearance of $\mathrm{FB}$ at the end of the experiment was unexpected given FB has been used in few other studies, especially in salmonid breeding programs, where the FB marks were readable in adults [48]. Cane [49] showed that in Rainbow Trout, Oncorhynchus 


\begin{tabular}{|c|c|c|c|c|}
\hline \multirow{3}{*}{$\%$ of fin regenerated } & \multicolumn{4}{|c|}{ Marking Methods } \\
\hline & \multicolumn{2}{|c|}{ AF-C } & \multicolumn{2}{|c|}{ AF-IC } \\
\hline & $4 \mathrm{~m}$ & $10 \mathrm{~m}$ & $4 \mathrm{~m}$ & $10 \mathrm{~m}$ \\
\hline $0 \%$ Adipose Fin & 97 & 97 & -- & -- \\
\hline $25 \%$ Adipose Fin & 3 & 3 & 57 & 46 \\
\hline $50 \%$ Adipose Fin & -- & -- & 42 & 51 \\
\hline 75\% Adipose Fin & -- & -- & 1 & 1 \\
\hline 100\% Adipose Fin & -- & -- & -- & 1 \\
\hline
\end{tabular}

Table 5: Regeneration of complete and incomplete $(75 \%)$ removal of adipose fin (\%) at 4 and 10 months of the experimental period in experiment III.

\begin{tabular}{|c|c|c|c|c|}
\hline Marking method & Salary & Capital cost & Materials & Total cost \\
\hline Manual AFC & $480-600$ & $\sim 0$ & $\sim 0$ & $480-600$ \\
\hline Manual FB & $670-830$ & $\sim 0$ & $\sim 0$ & $670-830$ \\
\hline Manual VIE & 830 & $\sim 0$ & 590 & 1420 \\
\hline Semi-automatic AFC & $60-200$ & $20-30$ & $\sim 0$ & $80-230$ \\
\hline Semi-automatic FB & $480-600$ & $20-30$ & $\sim 0$ & $500-630$ \\
\hline Semi-automatic VIE & $480-600$ & $20-30$ & 590 & $1090-1220$ \\
\hline Full automatic AFC & $30-33$ & 10 & $\sim 0$ & $40-43$ \\
\hline Full automatic FB & $480-600$ & $20-30$ & $\sim 0$ & $500-630$ \\
\hline
\end{tabular}

Table 6: Estimated cost of external marking of 1000 Atlantic salmon smolts in Norway (in NOK). It is assumed that automated marking occurs simultaneously with vaccination. Labour cost was set to $600 \mathrm{NOK} \mathrm{hr}{ }^{-1}$

mykiss, the retention rate of FB marking was higher up to one month and thereafter the retention rate was significantly decreased and was below $50 \%$ after 3 months post marking. The major difference between FB in our experiment and the breeding programs and other studies was that we applied the FB only for 3 seconds while breeding programs used the FB for longer than 3 seconds to burn the scales so that the marks were made directly on the skin $[10,44,50]$.

Considering the results of experiment II, mark retention of FB on both locations were very good in shorter term (4 months) but it was not suitable for long term marking. Retention of FB and VIE marks are shown to vary depending on the location of the mark on the fish [10,30,51]. Evrard [10] showed that FB had higher retention rates in roach Rutilus rutilus, however, the experiment was conducted only for 30 days. Peters et al. stated that FB might not be suitable for long term marking in their study with Coho salmon; however, they used $\mathrm{CO}_{2}$ as the FB agent and did not report timing of this application, thus difficult to compare with our study. However, Piggins [52] showed that $93 \%$ of the returning Atlantic salmon retained the FB, although the marks became less dark. Nevertheless, Piggins [52] used 1+ and 2+ year smolts and the handling time per fish was about 9 seconds (double the time as in our experiment). For VIE marking, base of the dorsal fin was suitable for short term studies compared to behind the eye lid and again VIE marking was not suitable for long term studies. Close [9] showed similar results in rainbow trout Oncorhynchus mykiss where she used green and yellow VIE tags injected posterior to the right and left eye. At the end of her study (195 days) all the tags became undetectable without UV light and with light 87 (yellow) and 57\% (green) of the tags were detectable.

Our results suggested that incomplete removal of the adipose fin would result in at least $25 \%$ regeneration. Regeneration of damaged tissue growth is a common phenomenon in animals and fin regeneration has been reported in many fish species [53]. Duke [54] indicated that regeneration of adipose fins in fish is relatively minimal compared to the other fins and he attributed any significant regeneration of adipose fins to inexperience and lack of skill of the personnel removing it. Thompson and Blankenship [46] showed that partial adipose fin removal resulted in complete regeneration of the fin in $23 \%$ (in addition to $35 \%$ to $63 \%$ of partial regeneration) of the returning Coho salmon adults after 21 months. However, complete removal of adipose fins did not show any regeneration. Similarly, in our experiment, complete removal of AF resulted in a partial regeneration of only one fish.

Duke [54] reported that the complete healing of AF clipping usually takes about 3-4 weeks depending on quality of the incision, fish health, water quality, and temperature, and size of the fish. Larger fish and deep incisions tend to have more tissue exposure thus prone to fungal infections. In general, healing process is faster in higher water temperature but secondary infections would also increase. Andrews et al. [55] have reported even faster wound closing and healing in Atlantic salmon smolts after AF removal. They also showed that wound closure was rapid in warm water but the wound closure was completed between $4-6$ hours at 10 and $14^{\circ} \mathrm{C}$ and $6-12$ hours at $4^{\circ} \mathrm{C}$. Regardless of temperature, superficial cells, cuboidal cells, prismatic basal cells and mucous cells were evident in all temperature groups at $18 \mathrm{~h}$ postclipping and regained the normal epidermal structure and thickness. Thus, the removal of AF may not contribute to any direct mortality of the parr and smolts and this was confirmed by the survival data of parr and smolts from our study. Petersson et al. [12] also suggested that multiple fin removal and single removal of pelvic or pectoral fins are harmful for brown trout (Salmo trutta) but removal of adipose fin can be performed without affecting the welfare of the fish.

The cost of any of the marking methods in a commercial set up will depend upon the capital and labour cost. When considering a manual operation, marking millions of fish would be time consuming and labour intensive. Our analysis showed that cost of marking the fish with any one of the three methods we tested would depend on whether it is automated or not. For FB, fish were kept in contact with cold metallic rod for 3 seconds, but this has proven to be too short in terms of achieving good durability marks. It is suggested that a $4-5$ seconds contact time is necessary to achieve a durable FB marking $[44,10]$. Therefore, with a 4 seconds contact time, the total time for handling the fish would be 5-6 seconds for even skilled people. Similar results were reported by Piggins [52] for freeze branding Atlantic salmon smolts. This will translate to $600-720$ fish person ${ }^{-1} \mathrm{~h}^{-1}$. While no measurement of time needed to inject VIE to one fish was taken, it was noted that it took considerably longer than in the two other noteworthy methods. Haines et al. [56] have suggested that it may take 10-12 seconds for a person to perform a VIE injection. However, other studies have suggested that it would take 3-4 seconds per fish to inject a VIE marking by a welltrained person [57]. Use of compressed air driven injector can also reduce the time spent and the rate will be increased by training.

Fin clipping can be automated without having negative effects on fin clip quality and injury rate [11]. It is a practice that all the Atlantic salmon smolts are vaccinated before transferring them to sea cages. It is recommended that any marking of fish should be combined with vaccination to reduce the use of anaesthesia and handling stress. It is also obvious that combining vaccination and tagging is far more cost effective than performing this in two separate operations. Manual vaccination has a capacity to vaccinate up to 2500 fish hour $^{-1}$ person ${ }^{-1}$ (personal observation) which corresponds to about 1.5 seconds per fish. In contrast, adipose fin clipping takes longer time. A seasoned team of 4 people at the Big Qualicum Hatchery (BC, Canada), which managed clipping adipose fin for 40,000 fish on a workday or 1250 fish person ${ }^{-1}$ $\mathrm{h}^{-1}$ (personal observation). Manual adipose fin clipping therefore takes about twice as long as manual vaccination. So combining vaccination and fin clipping in one operation will reduce the efficiency of the 
Citation: Mortensen A, Hansen OJ, Puvanendran V (2016) Evaluation of Three External Marking Methods of Farmed Atlantic Salmon for the Future Use of Differentiating it From Wild Atlantic Salmon. J Aquac Res Development 7: 451. doi: 10.4172/2155-9546.1000451

vaccination by half. Similar numbers were also reported by WingVax AS (7255 Sundlandet, Norway) which manually vaccinates the salmon in Norway while testing vaccines and mark them with fin clipping (personal communication). Thus, methods and machineries should be developed for combined operation of automated fin clipping and vaccination

\section{Conclusion}

Freeze branding, irrespective of the location, failed to produce better mark retainability in longer term. While VIE marking retention was better than the freeze branding, it resulted in a maximum of $61 \%$ mark retention in longer term which was not satisfactory. However, complete adipose fin clipping, gave a $97 \%$ mark retainability and considering the results from all three experiments and the experiment conducted by the Norwegian Veterinary Institute, the complete removal of adipose fin is the best marking method among the 3 methods tested to mark the farmed salmon to differentiate them externally from wild fish. However, our experiment was conducted in a relatively small scale and the all the marking were done in laboratories under better hygienic conditions, thus similar study in a commercial size sea cage need to be undertaken to confirm our results. Further better-automated AF clipping methods in combination with vaccination needs to be developed to make this marking method economically efficient.

\section{Acknowledgement}

We would like to thank all the staff at the Aquaculture Research Station in Kårvika and the staff at the sea cage site. We also thank Mr. Glen Graf, Regional Headquarters, Fisheries and Oceans Canada, Vancouver for his help at the early stage of this project. This project was funded by the Fishery and Aquaculture Industry Research (FHF; project number-900707)

\section{References}

1. Fisheries Directorate Report (2014).

2. Jacobsen JA, Hansen LP (2001) Feeding habits of wild and escaped farmed Atlantic salmon, Salmo salar L., in the Northeast Atlantic. ICES J Mar Sci 58: 916-933.

3. Jensen $\varnothing$, Dempster T, Thorstad EB, Uglem I, Fredheim A (2010) Escapes of fishes from Norwegian sea-cage aquaculture: causes, consequences and prevention. Aquacult Environ Interact 1: 71-83.

4. Schiermeier Q (2003) Fish farms' threat to salmon stocks exposed. Nature 425 : 753.

5. Glover KA, Skilbrei OT, Skaala Ø (2008) Genetic assignment identifies farm of origin for Atlantic salmon Salmo salar escapees in a Norwegian fjord. ICES J Mar Sci 65: 912-920.

6. Chart TE, Bergersen EP (1988) Methods for long-term identification of salmonids: A review. Colorado State University, Fort Collins Dept. of Fishery and Wildlife Biology.

7. Bonneau JL, Thurow RF, Scarnecchia DL (1995) Capture, marking, and enumeration of juvenile bull trout and cutthroat trout in small, low conductivity streams. North American Journal of Fisheries Management 15: 563-568.

8. Bailey RE, Irvine JR, Dalziel FC, Nelson TC (1998) Evaluations of visible implant fluorescent tags for marking Coho salmon smolts. North American Journal of Fisheries Management 18: 191-196.

9. Close TL (2000) Detection and retention of post-ocular visible implant elastomer in fingerling rainbow trout. North American Journal of Fisheries Management 20: $542-545$

10. Evrard G (2004) Use and effect of freeze branding on roach (Rutilus rutilus L.). Bulletin Français de la Pêche et de la Pisciculture 374: 35-42.

11. Hand DM, Brignon WR, Olson DE, Rivera J (2010) Comparing two methods used to mark juvenile Chinook salmon: automated and manual marking. North American Journal of Fisheries Management 72: 10-17.

12. Petersson E, Rask J, Ragnarsson B, Karlsson L, Persson J (2014) Effects of fin-clipping regarding adult return rates in hatchery-reared brown trout. Aquaculture 422: 249-252.
13. Sweeting RM, Beamish RJ, Noakes DJ, Neville CM (2003) Replacement of wild Coho salmon by hatchery-reared Coho salmon in the Strait of Georgia over the past three decades. North American Journal of Fisheries Management 23: 492-502.

14. Lund RA, Hansel LP (1991) Identification of wild and reared Atlantic salmon, Salmo salar L., using scale characters. Aquaculture Research 22: 499-508.

15. Glover KA (2010) Forensic identification of fish farm escapees: the Norwegian experience. Aquacult Environ Interact 1: 1-10.

16. Karlsson S, Moen T, Lien S, Glover KA, Hindar K (2011) Generic genetic differences between farmed and wild Atlantic salmon identified from a 7K SNP. chip. Molecular Ecology Resources 11: 247-253.

17. Skaala $\varnothing$, Glover KA, Barlaup BT, Svåsand T, Besnier F, et al. (2012) Performance of farmed, hybrid, and wild Atlantic salmon (Salmo salar) families in a natural river environment. Canadian Journal of Fisheries and Aquatic Sciences 69: 1994-2006

18. Hastein T, Hill BJ, Berthe F, Lightner DV (2001) Traceability of aquatic animals Revue Scientifique Et Technique De L Office International Des Epizooties 20: 564-583.

19. Warren-Myers F, Dempster T, Fjelldal PG, Hansen T, Swearer SE (2015) Mass marking farmed Atlantic salmon with transgenerational isotopic fingerprints to trace farm fish escapees. Aquacult Environ Interact 7: 75 .

20. Hammer SA, Lee BH (2001) Cost comparison of marks, tags, and mark with-tag combinations used in salmonid research. North American Journal of Fisheries Management 63: 171-178.

21. Arechavala-Lopez P, Fernandez-Jover D, Black KD, Ladoukakis E, BayleSempere JT, et al. (2013) Differentiating the wild or farmed origin of Mediterranean fish: a review of tools for sea bream and sea bass. Reviews in Aquaculture 5: 137-157.

22. Gilbey J, Knox D, O'Sullivan M, Verspoor E (2005) Novel DNA markers for rapid, accurate, and cost-effective discrimination of the continental origin of Atlantic salmon (Salmo salar L.). ICES J Mar Sci 62: 1606-1616.

23. Gjerde B, Refstie T (1988) The effect of fin-clipping on growth rate, survival and sexual maturity of rainbow trout. Aquaculture 73: 383-389.

24. Thorsteinsson $V$ (2002) Tagging methods for stock assessment and research in fisheries. Report of Concerted Action FAIR CT.96.1394 (CATAG). Reykjavik.

25. Skalski JR, Buchanan RA, Griswold J (2009) Review of marking methods and release-recapture designs for estimating the survival of very small fish: examples from the assessment of salmonid fry survival. Reviews in Fisheries Science 17: 391-401.

26. Willis T, Babcock R (1998) Retention and in situ detectability of visible implant fluorescent elastomer (VIFE) tags in Pagrus auratus (Sparidae). New Zealand Journal of Marine and Freshwater Research 32: 247-254.

27. Mahapatra KD, Gjerde B, Reddy PVGK, Sahoo M, Jana RK, et al. (2001) Tagging: on the use of passive integrated transponder (PIT) tags for the identification of fish. Aquaculture Research 32: 47-50.

28. Serafy JE, Lutz SJ, Capo TR, Ortner PB, Lutz PL (1995) Anchor tags affect swimming performance and growth of juvenile red drum (Sciaenops ocellatus). Marine and Freshwater Behaviour and Physiology 27: 29-35.

29. Bridger CJ, Booth RK (2003) The effects of biotelemetry transmitter presence and attachment procedures on fish physiology and behavior. Reviews in Fisheries Science 11: 13-34

30. FitzGerald JL, Sheehan TF, Kocik JF (2004) Visibility of visual implant elastomer tags in Atlantic salmon reared for two years in marine net-pens. North American Journal of Fisheries Management 24: 222-227.

31. Wagner CP, Einfalt LM, Scimone AB, Wahl DH (2009) Effects of fin-clipping on the foraging behavior and growth of age-0 muskellunge. North American Journal of Fisheries Management 29: 1644-1652.

32. Cunjak RA, Roussel JM, Gray MA, Dietrich JP, Cartwright DF, et al. (2005) Using stable isotope analysis with telemetry or mark-recapture data to identify fish movement and foraging. Oecologia 144: 636-646.

33. Bellona Report (2013) Traditional and integrated aquaculture: Today's environmental challenges and solutions of tomorrow. The Bellona Foundation, Norway.

34. Jensen LF, Hansen MM, Thomassen ST (2008) Visible implant elastomer 
Citation: Mortensen A, Hansen OJ, Puvanendran V (2016) Evaluation of Three External Marking Methods of Farmed Atlantic Salmon for the Future Use of Differentiating it From Wild Atlantic Salmon. J Aquac Res Development 7: 451. doi: 10.4172/2155-9546.1000451

(VIE) marking of brown trout, Salmo trutta, alevins. Fisheries Management and Ecology 15: 81-83.

35. Walsh MG, Winkelman DL (2004) Anchor and visible implant elastomer tag retention by hatchery rainbow trout stocked into an Ozark stream. North American Journal of Fisheries Management 24: 1435-1439.

36. Northwest Marine Technology Inc. (2008) Visible Implant Elastomer Tag Project Manual: Guidelines on planning and conducting projects using VIE and associated equipment.

37. Kitahara T (1983) Behavior of carotenoids in the chum salmon (Oncorhyncus keta) during anadromous migration. Comparative Biochemistry and Physiology B 67: 97-101.

38. Bjerken B, Storebakken T, Liaanen-Jensen S (1992) Pigmentation of rainbow trout from start feeding to sexual maturation. Aquaculture 108: 333-346.

39. Haner PV, Faler JC, Schrock RM, Rondorf DW, Maule AG (1995) Skin reflectance as a nonlethal measure of smoltification for juvenile salmonids. North American Journal of Fisheries Management 15: 814-822.

40. Bjornn TC (1978) Survival, production, and yield of trout and Chinook salmon in the Lemhi River, Idaho. University of Idaho, College of Forestry, Wildlife and Range Sciences Bulletin.

41. Everest FH (1973) Ecology and management of summer steelhead in the Rogue River. Fishery Research Report 7, Oregon State Game Commission, Corvallis.

42. Thompson JM, Hirethota PS, Eggo BT (2005) A comparison of elastomer marks and fin clips as marking techniques for walleye. North American Journal of Fisheries Management 25: 308-315.

43. Champion AS, Hill HJ (1974) A comparison of pre-migration mortality of hatchery-reared salmon smolts which had been tagged or liquid nitrogen coldbranded. Aquaculture Research 5: 23-24.

44. Fay CW, Pardue GB (1985) Freeze brands and submandibular latex injections as identifying marks on rainbow trout. North American Journal of Fisheries Management 5: 248-251.

45. Olsen EM, Vøllestad LA (2001) An evaluation of visible implant elastomer for marking age-0 brown trout. North American Journal of Fisheries Management 21: $967-970$
46. Thompson DA, Blankenship HL (1997) Regeneration of adipose fins given complete and incomplete clips. North American Journal of Fisheries Management 17: 467-469.

47. McFarlane GA, Wydoski RS, Prince ED (1990) Historical review of the development of external tags and marks. American Fisheries Society Symposium 7: 9-29.

48. Gjedrem T (2010) The first family-based breeding program in aquaculture Reviews in Aquaculture 2: 2-15.

49. Cane A (1981) Tests of some batch-marking techniques for rainbow trout (Salmo gairdneri Richardson). Aquaculture Research 12: 1-8.

50. Refstie T (1990) Application of breeding schemes. Aquaculture 85: 163-169

51. Reeves KS, Buckmeier DL (2009) Mortality, predation, and tag visibility of fish marked with visible implant elastomer tags. North American Journal of Fisheries Management 29: 323-329.

52. Piggins DJ (1972) Cold branding as a smolt marking technique. Aquaculture Research 3: 9-11.

53. Akimenko MA, Marí-Beffa M, Becerra J, Géraudie J (2003) Old questions, new tools, and some answers to the mystery of fin regeneration. Developmental dynamics 226: 190-201.

54. Duke R (1986) Protection of wild adult steelhead in Idaho by adipose fin removal: Annual report. Bonneville Power Administration, Division of Fish and Wildlife.

55. Andrews M, Stormoen M, Schmidt-Posthaus H, Wahli T, Midtlyng PJ (2015) Rapid temperature-dependent wound closure following adipose fin clipping of Atlantic salmon Salmo salar L. Journal of Fish Diseases 38: 523-531.

56. Astorga N, Afonso JM, Zamorano MJ, Montero D, Oliva V, et al. (2005) Evaluation of visible implant elastomer tags for tagging juvenile gilthead seabream (Sparus auratus L.): effects on growth, mortality, handling time and tag loss. Aquaculture Research 36: 733-738.

57. Haines GB, Severson SH, Modde T (1998) Evaluation of razorback sucker and Colorado squawfish batch marking techniques. Progressive Fish Culturist 60 : 272-275. 